rarnoyi osvity v Ukrayini : Monohrafiya / H. D. Berehova. - Kherson : Aylant, 2012. - 312 s.

4. Berehova H.D. Svitohlyad osobystosti yak riven' filosofs'koho osmyslennya svitu / H.D. Berehova // Filosofs'kyy al'manakh «Mul'tyversum»; [Hol. red. Lyakh V.V.] - Vypusk 1 (109). K.: Instytut filosofiyi im. H.S. Skovorody NANU, 2012. - S. 159-169.

5. Bekh V.P. Chelovek y Vselennaya: kohnytyvnыy analyz: Monohrafyya; [2-e yzd. dop] / V.P. Bekh. - Zaporozh'e: Prosvyta, 1999. - 148 s.

6. Kaps'ka A.Y. Sotsial'na pedahohika: pidruchnyk. - [3-tye vyd., pererob. i dop.] / [za red. A.Y. Kaps'koyi]. - K.: Tsentr uchbovoyi literatury, 2006. - $468 \mathrm{~s}$.

7. Menehetty A. Osnovы fylosofyy; [per. s ytal'yan. NNBF Ontopsykholohyya]. / Antonyo Menehetty. - M.: Ontopsykholohyya, 2007. - 268 s.

8. Novychkova H.A. Ystoryko-fylosofskye ocherky zapadnoy pedahohycheskoy antropolohyy / H.A. Novychkova. - M.: YF RAN, 2001. - 142 s.

9. Petrovskyy V.A. Lychnost' v psykholohy: paradyhma subъektnosty / V.A. Petrovskyy. Rostov-na-Donu: Fenyks, 1996. - 512 s.

10. Stepanov O.M. Pedahohichna psykholohiya: Navchal'nyy posibnyk / O.M. Stepanov. - K.: Akademvydav, 2011. - 416 s.

Надійшла 24.01.2018

Бібліографбічний опис для цитування:

Берегова Г. Д. Міждисциплінарний статус і багатовимірність категорії «особистість» / Г. Д. Берегова // Sophia Prima: діалог вічного повернення. - 2019. - № 1. - С. 20-25.
УДК 159.9.01

I.М. Біла,

д. психол. н., професор

\section{ГЕНЕЗА ОСОБИСТОСТІ В УМОВАХ СІМЕЙНОЇ ВЗАЄМОДІЇ}

У ході вивчення проблеми генези, становлення особистості в умовах сім'ї нами доведено, що сімейна взаємодія є основним фактором формування особистісних орієнтирів, які визначають життєву траєкторію, вектор розвитку здібностей, успішної життєвої стратегії.

З'ясовано, що у сім'ї наряду з іншими формуються навички спілкування, взаємодіï, здібності та особистісні характеристики, які забезпечують успіх у виконанні різноманітних діяльностей. Встановлено зв'язок між умовами життя, виховання в сім'ї і типом особистості дитини та з'ясовано найбільш поширені розвивальні джерела.

Важливим $є$ демократичний стиль виховання, що характеризується високим ступенем вербального спілкування між батьками $і$ дітьми, включеністю дітей в обговорення сімейних проблем, готовністю батьків завжди прийти на допомогу, прагненням до зниження суб'єктивності в баченні дитини, заохоченням активносmi, допитливості, креативності, наданням свободи дій та інформації про об'єкт чи явище, які цікавлять дитину. За цих умов інтерес, активність та пізнавальний досвід дитини забезпечує формування когнітивно-творчих основ їі особистості; заохочення та підтримка естетичних, моральних потреб сприяє формуванню особистісно-ціннісного підгрунтя індивіда; формування вольових якостей та емоційних процесів забезпечує мотиваційно-вольовий аспект розвитку гармонійної особистості.

Посилення позитивного розвивального взаємовпливу в сім'ї проявляється у зростанні рівня педагогічної грамотно- 
сті батьків, що позначається на розвитку, поведінці дитини та сприяє розквіту її особистості.

Ключові слова: особистість, генеза особистості, сім'я, сімейна взаємодія.

Била И.Н. Генезис личности в условиях семейного взаимодейсвия.

В ходе изучения проблемы генезиса личности в условиях семьи нами доказано, что семейное взаимодействие является основным фактором формирования личностных ориентиров, которые определяют жизненную траекторию, вектор развития способностей, успешной жизненной стратегии.

Выяснено, что в семье наряду с другими формируются и навыки общения, взаимодействия, способности и личностние характеристики которые обеспечивают успех в выполнении различных деятельностей. Установлена связь между условиями жизни, воспитания в семье и типом личности ребенка, а также наиболее распространенные развивающие источники.

Важным является демократический стиль воспитания, который характеризуется высокой степенью вербального общения между родителями и детьми, включенностью детей в обсуждение семейных проблем, готовностью родителей всегда прийти на помощь, стремлением $к$ снижению субъективности в оценке ребенка, поощрением активности, любознательности, креативности, предоставлением свободы действий и информации об объекте или явлении, которые интересуют ребенка. В этих условиях интерес, активность и познавательный опыт ребенка обеспечивает формирование когнитивно-творческих основ его личности; поощрение и поддержка эстетических, нравственных потребностей способствует формированию личностно-ценностного базиса индивида; формирование волевых качеств и эмоциональных процессов обеспечивает мотивационно-волевой аспект развития гармоничной личности.

Усиление позитивного развивающего взаимовлияния в семье проявляется в росте уровня педагогической грамотности родителей, что сказывается на развитии, поведении ребенка и способствует расцвету его личности.

Ключевые слова: личность, генезис личности, семья, семейная взаимодействие.

Bila I.N. Genesis of personality in conditions of family interaction

During our studies for the problem creating personality in the family environment, we proved that family interaction is done by creating personal targets that define the life trajectory, vector of ability, successful life strategy.

It was found that in the family, along with other emerging and communication skills, interaction, abilities, personal characteristics and ensure success in the implementation of various activities and as a result - successful adaptation. It was found connection between the living conditions and upbringing in the family and the type of child. According to the studies, the most common developmental sources. The most important way is the democratic style of family upbringing, characterized by a high degree of verbal communication between parents and children, inclusion of children in discussing family problems, willingness of the parents always come to the rescue, promotion of being active, curiosity, creativity, providing child leeway.

Family interaction that activates the cognitive, productive activities, maintains interest and motivation to its process, stimulates the development of personal-value, cognitive and creative areas and is an essential factor of formation and manifestation abilities of the child that can adapt to any, even the difficult living conditions. 
Enhancing positive developmental interference in the family manifested in increasing the level of pedagogical knowledge of the parents, which affects the development, the child's behavior and contributes to the genesis of personality.

Keywords: personality, genesis of personality, family, family interaction.

Актуальність теми дослідження. В умовах сучасного глобалізованого суспільства важливим стає демократичний стиль виховання, що характеризується високим ступенем вербального спілкування між батьками і дітьми, включеністю дітей в обговорення сімейних проблем, готовністю батьків завжди прийти на допомогу, прагненням до зниження суб'єктивності в баченні дитини, заохоченням активності, допитливості, креативності, наданням свободи дій та інформації про об'єкт чи явище, які цікавлять дитину. За цих умов інтерес, активність та пізнавальний досвід дитини забезпечує формування когнітивно-творчих основ її особистості; заохочення та підтримка естетичних, моральних потреб сприяє формуванню особистісно-ціннісного підгрунтя індивіда; формування вольових якостей та емоційних процесів забезпечує мотиваційно-вольовий аспект розвитку гармонійної особистості.

Посилення позитивного розвивального взаємовпливу в сім'ї проявляється у зростанні рівня педагогічної грамотності батьків, що позначається на розвитку, поведінці дитини та сприяє розквіту іï особистості, осмислення означеної проблематики, надання практичних рекомендацій $\epsilon$ безперечно актуальним завданням для даного дослідження.

Аналіз останніх досліджень і публікацій. Відомі психологи Л.С. Виготський, С.Л. Рубінштейн, П.Я. Гальперін, Л.І. Божович, B.C. Мухіна та багато інших, в якості домінуючої сторони в розвитку особистості називають соціальний досвід. У процесі засвоєння цього досвіду відбувається не лише набуття окремих знань та досвіду, але й формування особистості.

У дієвому контакті з оточуючим світом, в процесі поступового засвоєння досягнень попереднього історичного розвитку людства, що здійснюється в ході навчання та виховання відбувається становлення особистості Л.С. Виготський, В.В. Давидов, Г.С. Костюк, С.Л. Рубінштейн та інщі. При цьому важливим $є$ фактор середовища, простору соціальної взаємодії, в якому індивід знаходить стимули для самонавчання та саморозвитку саме на початковому етапі онтогенезу, який $\epsilon$ визначальним для формування особистості. Адже у дитинстві особистість «виробляється» (В.В. Давидов) за умов створення такого середовища, яке б забезпечувало розвивальну взаємодію, особлива роль у якій відводиться спільності «дитина-дорослий».

Постановка завдання. Згідно досліджень таких науковців як Т.В. Говорун, С.О. Ладивір, М.І. Лісіна, Е.Г. Ейдеміллер, Т.М. Яблонська, першою і головною "школою” соціального досвіду є сім'я. Саме тому завданням нашого дослідження $\epsilon$ визначення ролі сімейної взаємодії у формуванні, розвитку особистості.

Виклад основного матеріалу. Згідно результатів попередніх досліджень, усі компоненти структури здібностей особистості (мотиваційно-вольовий, особистісно-ціннісний, операційно-діяльнісний, когнітивно-творчий) можуть успішно розвиватися лише за умови наявності розвивального середовища, простору, в якому сім'я займає визначальне місце (див. структурна модель розвитку здібностей) [1]. Адже сім'я $є$ первинною мікросистемою соціуму, через яку індивід засвоює знання, а також виступає головним агентом впливу на особистість, що детермінує ті чи інші їі якості та характеристики. Сім'я - це певний морально-психологіч- 
ний клімат, школа стосунків з людьми. Саме в сім'ї складаються уявлення дитини про добро і зло, про порядність, про поважне ставлення до матеріальних та духовних цінностей. У сім'ї закладаються та формуються суб'єктивні цінності, які є згодом внутрішнім регулятором діяльності, особистісного розвитку.

Так, у результаті проведення "середовищної” дослідницької програми B.M. Дружиніним було з'ясовано, що саме від сімейного середовища залежить розвиток творчих здібностей (здібності до розумової творчості), невербального інтелекту та парціальних здібностей (пам'яті, уваги, сенсомоторики). В роботі О.Л. Григоренко та Б.І. Кочубея, доведено, що рівень розвитку вербальної та невербальної креативності (загальної творчої здібності) залежить від широти кола спілкування та наявності в сім'ї демократичного стилю виховання, а величина генетичної зумовленості більшості особистісних якостей (виключаючи темперамент) значно нища від показників наслідуваності загальних та спеціальних здібностей [5, с. 135]. Це пояснюється тим, що діти зазвичай прагнуть копіювати поведінку тих, з ким вони знаходяться в самому близькому контакті. Почасти це свідома спроба поводити себе так само, як поводять себе значимі дорослі, почасти - неусвідомлена імітація, яка є одним з аспектів ідентифікації з іншим.

На думку Е. Берна, долею людини у значній мірі керує “батьківське програмування. Цей неусвідомлений процес Е.Берн називає скриптуванням - формування сценарію, життєвого плану у дитинстві під впливом батьків. Меседжі, які батьки неодноразово повторюють закарбовуються у підсвідомі настановлення і визначають майбутні ціннісні орієнтації, здібності. Спілкування з дорослими, які виховують дитину, є для неї джерелом не порівняним ні з чим іншим яскравих, особисто адресованих їй впливів, стимулів та зразків (О.О. Смирнова, С.Ю. Мещерякова, А.Г. Рузская, М.I. Лісіна та інші) [6, с. 25].

Це демонтрує аксіоматичність тези Л.С.Виготського про те, що всі вищі психічні функції людини першочергово формуються як зовнішні, тобто такі, в реалізації яких бере участь не один, а мінімум два суб'єкта. I лише поступово вони стають внутрішніми, перетворюються 3 «інтерпсихічних» в «інтрапсихічні». Розробка поглядів Л.С. Виготського призвела до створення оригінальної концепції дитячого розвитку, в рамках якої розвиток дитини розуміється як процес присвоєння дітьми суспільно-історичного досвіду, накопиченого попередніми поколіннями людства (О.М. Запорожець, О.М. Леонтьєв, Д.Б. Ельконін). Спілкування з дорослими для маленької дитини служить єдино можливим контекстом, в якому вона засвоює та «привласнює» добуте людьми раніше [6, с. 17]. Саме сімейна взаємодія, "психічна стимуляція”, яка відбувається при спілкуванні та сумісній діяльності дитини і дорослих $\epsilon$ вирішальним середовищним фактором розвитку інтелекту дітей. Так, наприклад, результати проведеного B.M. Дружиніним дослідження засвідчили, що ті, хто отримував емоційну підтримку експериментатора краще розв'язують тестові завдання, а наявність чи відсутність контролю за поведінкою дитини значно не впливає на результи вимірювання інтелекту. Тобто не когнітивно-поведінковий контроль, а емоційна підтримка, створення певної емоційної обстановки значно впливає на результат розумової діяльності дитини. При відсутності контролю поведінки та емоційної підтримки розумні діти починають боятися невдачі. Навпаки, при високому контролі за поведінкою та емоційній підтримці (домінуюча гіперпротекція) у низькоінтелектуальних дітей розвивається мотивація успіху. При збереженні емоційної підтримки та відсутності жорсткого констролю зі сторони 
дорослого підвищується інтелектуальна продуктивність [5, с. 150].

Все це відповідає увленням Л.С. Виготського про "зону наближчого розвитку: будь-яке підтримуюче втручання дорослого покращує результат розв'язання задачі. Загалом вплив спілкування на психічний розвиток дитини відбувається завдяки: 1) сприятливим «об'єктивним» якостям дорослого, які поєднуються 3 його властивостями як суб'єкта спілкування; 2) збагаченню дорослими досвіду дітей; 3) прямої постановки дорослими задач, які потребують від дитини оволодіння новими зняннями, вміннями та здібностями; 4) на основі підкріплюючої дії думок та оцінок дорослого; 5) можливості для дитини черпати у спілкуванні зразки дій та вчинків дорослих; 6) сприятливих умов для розкриття дітьми свого творчого, самобутнього начала [6, с. 30].

Вирішальну роль спілкування в загальному психічному розвитку дитини доводять, на думку М.I. Лісіної, три групи фактів, зокрема: 1) вивчення дітей-«Мауглі» (у дітей, які виросли в ізоляції від суспільства спостерігається глибокий та незворотній недорозвиток); 2) дослідження природи та причин госпіталізму (відхилення, що пов'язані з відсутністю материнського догляду, зокрема у дітей, що виховуються у дитячих будинках); 3) прямий вияв впливу спілкування на психічний розвиток у формуючих експериментах [6, с. 25].

Підтвердженням цьому $є$ також результати дослідження, отримані Скіллсом та його співробітниками в 30-ті роки в одному з пансіонатів для розумово відсталих дітей штату Айова. Всього в групу входило 25 малюків, ці діти весь час лежали у своїх ліжках і були відділені один від одного шторами. Було помічено, що діти, які виросли в таких умовах, як правило, ніколи не досягають нормального рівня інтелектуальної адаптації, більшість залишається в клініках для розумо- во неповноцінних. Скіллс взяв 13 дітей і помістив у заклад для розумово неповноцінних жінок. Жінки дуже скоро емоційно прийняли немовлят, доглядали за ними, розмовляли та пестили. Згодом діти почали прискорено розвиватися, інтелект їх досяг норми, і практично всі вони у майбутньому стали повноцінними членами суспільства (четверо отримали вищу освіту) [4, с. 97].

Спілкування, на думку вчених, так само необхідне дитині, як їжа. Малюк, який отримує повноцінне харчування та гарний медичний догляд, але обділений постійних контактів з дорослими, погано розвивається не лише психічно, але й фізично. Помічено, що коли дітей виховують в дитячому садку, де спілкування дитини з дорослим зводиться до мінімуму, так як на одного вихователя приходиться більше 10 дітей, то вони відстають від своїх ровесників, які виховуються в сімї, в інтелектуальному і сенсомоторному розвитку [4].

Було остаточно встановлено, що для виживання та розвитку дитині необхідно, щоб з нею гралися, розмовляли декілька разів на день. Людське спілкування є життєво важливим для дитини. Відомий сімейний терапевт Вірджинія Сатір рекомендує обіймати дитину декілька разів в день, стверджуючи, що чотири обійми необхідні кожному просто для виживання, а для хорошого самопочуття потрібно не менше восьми обіймів в день! [3, c.12]. Для правильного психічного розвитку маленької дитини першочерговим є стосунки з матір'ю (Дж. Боулбі, Р. Спітц, А. Фрейд та інші). Нестача спілкування 3 нею, ставить під загрозу життя дитини, перешкоджає їі фізичному та психічному розвитку. Дефіцит спілкування в ранньому віці накладає рокову печать на наступну долю особистості, визначаючи формування у неї агресивності, антисуспільних нахилів та душевної спустошеності [6, с. 4]. Тобто без постійної уваги, емоційно- 


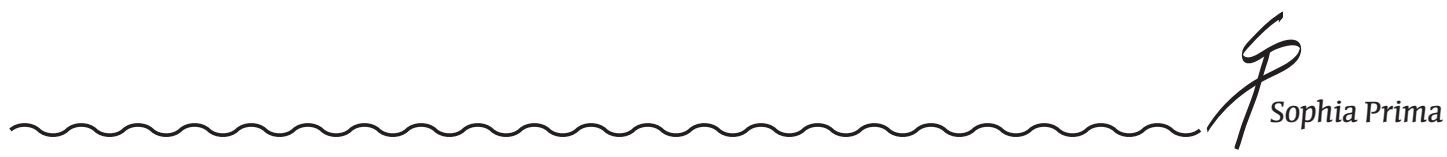

го спілкування з дорослим розвиток малюка уповільнюється, що призводить до різноманітних психологічних порушень i труднощів.

Вчені звертають увагу на госпіталізацію - хворобу, яка виникає у дитини при недостатності спілкування 3 дорослим. Посмішка, ласкаві слова, дотик до тіла дитини, обійми - з цього складається невловима і така важлива форма виховання, яку ми називаємо безпосередньо-емоційним спілкуванням.

B.M. Дружинін зауважує, що любов, емоційна близькість та підтримка, яку висловлюють один одному члени родини у православній традиції має велике значення [5, с. 137]. Більше всього благополуччю дитини сприяє доброзичлива атмосфера й така система сімейних взаємостосунків, яка дає відчуття захищеності та одночасно стимулює та спрямовує їі розвиток.

Вчені підкреслюють, що дитинства, повного любові, вистачає на все подальше життя. Дитина, яка недоотримала батьківської любові виростає недоброзичливою, озлобленою, черствою до переживань інших людей, зухвалою, невживчивою в колективі ровесників, інколи - замкнутою, занадто сором'язливою та невпевненою. Дитина, яка виросла в атмосфері надмірної любові, заласкування, благоговіння та пошанування, рано розвине в собі риси егоїзму та егоцентризму, зніженості, розбещеності, зазнайства та лицемірства.

Відомий психотерапевт B.I. Гарбузов застерігає від застосування неправильного виховання:

1. Виховання за типом А (неприйняття, емоційне відторгнення) - неприйняття індивідуальних особливостей дитини, що поєднується з жорстким контролем, 3 імперативним нав'язуванням їй єдино правильного типу поведінки. Тип виховання А може поєднуватися з нестачею контролю і навіть повним потуранням.
2. Виховання за типом В (гіперсоціалізуюче) виражається в тривожно-недовірливій конценції батьків про стан здоров'я дитини, іï соціальний статус серед товаришів, і особливо в школі, очікуванні успіхів в навчанні та майбутній професійній діяльності.

3. Виховання за типом С (егоцентричне) - культивування уваги всіх членів сімї на дитині, іноді на шкоду іншим дітям або членам сім'ї [10, с. 259].

Грунтовну класифікацію відхилень в стилях сімейного виховання (що співставляє особливості формування особистості дітей та стилів сімейного виховання) пропонують А.О. Лічко та Е.Г. Ейдеміллер:

Гіпопротекція характеризується нестачею опіки та контролю. Дитина залишається без нагляду. Невключеність дитини в життя сім'ї призводить до асоціальної поведінки із-за незадоволення потреби в любові та визнанні.

Домінуюча гіперпротекція виявляється в підвищеній, загостреній увазі та турботі, надмірній опіці та контролі поведінки, сліжці, заборонах та обмеженнях. Дитину не привчають до самостійності та відповідальності. Це призводить або до реакції емансипації, або до безініціативності, невмінню постояти за себе.

Гіперпротекція, как зване виховання “кумира сім'ї”. Батьки прагнуть звільнити дитину від найменших труднощів, потакають її бажанням, надмірно обожнюють та захоплюються ï успіхами і вимагають такого ж захоплення від інших. Результат такого виховання проявляється у високому рівні домагань, прагненні до лідерства, яке може поєднуватися з недостатньою завзятістю та опорою на свої сили.

Емоційне відторгнення - дитиною тяготяться, іï̈ потреби ігноруються. Іноді 3 нею жорстоко обходяться. Батьки вважають дитину обузою і проявляють загальне незадоволення нею. Часто зустрічається приховане емоційне відторгнення: батьки прагнуть завуалювати реальне 
ставлення до дитини підвищеною турботою та увагою до неї. Такий стиль виховання має найбільш негатвний вплив на розвиток дитини (втрата любові, втрата особистості, любові до «себе») [10, с. 262].

Встановлено, що лише незначна частина батьківської громади спроможна забезпечити гармонійний розвиток індивідуальності дитини $(14,5 \%)$. У більшості сімей відзначено схильність до парціального стилю виховання $(74,5 \%)$, в якому лише частково задовольняються потреби дитини, неповною мірою враховуються її індивідуальні відмінності, турбота про розвиток визначальних для індивідуальності властивостей проявляється епізодично. У значній кількості сімей виявлено спрямованість на дисгармонійний розвиток індивідуальності дитини (11\%).

До такого типу сімей відносяться сім'ї, що живуть за межею бідності. Бідність, на думку Т.В. Говорун, наражає родини, їхній побут, планування життя на "щоденні стреси”, які корелюють з багатьма негативними проявами-відставаннями в умінні навчатися в першу чергу. Брак пізнавальних умінь зафіксовано психологічними дослідженнями у дітей з бідних сімей вже з 3-4 років.

Встановлено, що економічні проблеми батьків з бідних сімей позначаються на ставленні до власних дітей: вони - або авторитарні у їх вихованні, більш роздратовані потребами догляду за ними, агресивні в ситуаціях фахової експертизи умов розвитку, значно більш прискіпливі до поведінки малечі, гнівливі та караючі за найменшої провини, не задовольняють навіть базові потреби дитини. Або ж набагато частіше, обирають нехтуючий, ігноруючий стиль виховання, байдужі не тільки до будь-яких потреб та інтересів дітей, але й до їхніх хвороб чи успіхів, маніпулюють ними, не переймаються поведінкою, харчуванням, вбранням, самопочуттям i, навіть, тривалою відсутністю дітей вдома. I ті, і інші нездатні до нормальної опіки та догляду за дітьми, емпатійного спілкування з ними, задоволення як біологічних, так і соціальних їхніх потреб, байдужі до їх життєдіяльності загалом. Вони більшою мірою, схильні виявляти негативні емоції щодо навколишнього світу, сусідів, вчителів, частіше пригноблюють дітей, застосовуючи фізичне і психічне їх покарання, що в сукупності не може не позначитися на астенічних або гіперастенічних психічних станах дітей.

Отже, економічний чинник поряд 3 іншими, у першу чергу, зумовлює несприятливий психологічний клімат родини, патологічні стилі сімейного виховання. Переживання відносної економічної депривації та фрустрації відіграє роль спускового механізму, який починає поширювати свій деструктивний вплив на зародження та розвиток тих особистісних складових, які зумовлюють норму психічного розвитку. Він стає достатньо вагомим у спричиненні ризику особистісного розвитку передовсім дітей сімей імігрантів, біженців, неповних, багатодітних родин, національних меншин, а також неповнолітніх матерів. Сучасні суспільні тенденції посилюють небезпеку розвитку. Згідно різних європейських джерел, датованих після 2000 року, один з 3-х дітей живе в бідності; 25 \% проживає 3 безробітними батьками; 40 \% в бідній неповній материнській родині [2].

Зв'язок між умовами життя і виховання в сім'ї та типом особистості дитини було виявлено й у дослідженнях Н.І.Непомнящої. Згідно отриманих результатів, у сім'ях дітей з цінісним фоном реально-звичного функціонування, найнижчим типом відносин «Я-інший» однією з провідних цінностей дуже часто вважаються матеріальне благополуччя, налагоджений побут, як правило, панує культ речових, практичних, а не особистісних відносин. Тому і дитину, ії̈ досягнення оцінюють з точки зору не стільки 


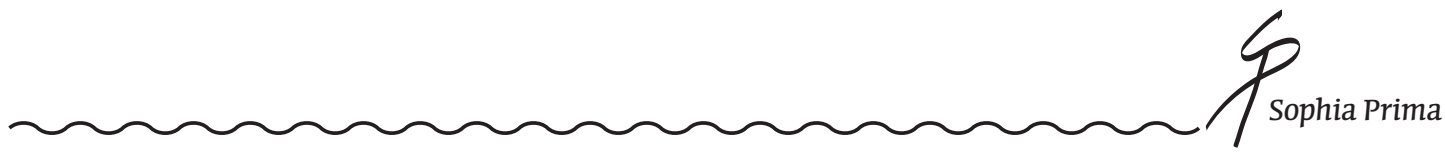

ïi особистості, скільки досягнутого результату. Переважання з боку близьких негативних оцінок, що накопичує досвід невдач призводить до того, що у багатьох дітей даної групи відсутня самостійність, вони невпевнені в собі, часто відчувають страх, виявляють негативізм, конфліктність, неадекватне сприйняття поведінки і ставлення до себе з боку інших дітей.

В сім'ях з універсальними ціностями (але такі діти, на жаль, становлять меншість) виховуються діти, 3 найвищими типами відносини «Я-інший», з високим рівнем розвитку здатності «бути собою та іншим», з високими показниками подолання обмеженості уявлень про світ і про себе, розвитку свідомості та діяльності. Дітям у таких сім'ях розповідають багато казок, вдома з ними багато граються, ігри та іграшки час від часу змінюють, при цьому діти часто самі придумують свої нові ігри. Характерною для цих сімей $€$ також відкритість сім'ї людям, різним інтересам, різноманітним і новим справам і т. д. У той же час існують сімейні традиції, випускається домашня газета і т.п. Все це формує в дітей прагнення до цікавого (у всіх сферах), нового, вдосконалення, творче ставлення до будь-якої справи.

Як правило в сім'ях, які відрізняє відкритість різним інтересам, справам, людям, різноманітність форм і змісту спілкування з дитиною, прояв уваги до інших людей, турбота про них, відповідальне і особистісне ставлення до різних видів діяльності і оцінка через таке ставлення особистості дитини, всіляке заохочення любові до ігор, визнається висока цінність освіти, виховуються обдаровані діти. Батьки особливу увагу приділяють навчанню своєї дитини, обираючи для неї книги, посібники, розвиваючі ігри тощо. Дітей і батьків об'єднують загальні пізнавальні інтереси, на основі яких виникають стійкі дружні відносини. Підтримка дорослих призводить до закріплення тих чи інших форм поведінки, реакція батьків визначає подальший розвиток здібностей та обдарувань дітей [7, с. 135].

Висновки та перспективи подальших досліджень. Динаміка формування всіх компонентів розвитку особистості, ïi здібностей, оволодіння пізнавальним, соціальним досвідом у більшості залежить від того, наскільки батьки забезпечують дитині змістовне пізнавальне спілкування, підтримують захоплення, інтереси дитини, пропонують різні пізнавальні, розвивальні джерела та стимули.

Загалом батькам варто дотримуватись принципів сімейного виховання, які пронизані гуманістичною ідеєю про найвищу цінність дитини, а саме:

- в основу сімейного виховання має бути покладено діалектичну єдність щирої, глибокої поваги до особистості та високої вимогливості до неї;

- батьки повинні зрозуміти і прийняти свою дитину такою, якою вона є, і сприяти розвитку в ній кращого; виховання має будуватися з опорою на позитивні основи в зростаючій людині, виховні впливи повинні будуватися з урахуванням вікових і індивідуальних особливостей;

- особистість самих батьків - ідеальна модель для наслідування дітьми;

- оптимізм і позитив - основа стилю і тону спілкування з дітьми в сім'ї.

Посилення позитивного розвивального взаємовпливу в сім'ї проявляється у зростанні рівня педагогічної грамотності батьків, що позначається на розвитку, поведінці дитини та сприяє розквіту ії особистості. Сімейна взаємодія, яка активізує пізнавальну, продуктивну діяльність, підтримує інтерес та мотивацію до неї, стимулює розвиток особистісно-ціннісної, когнітивно-творчої сфери $\epsilon$ необхідним фактором особистісного розвитку. Перспективою подальших досліджень $\epsilon$ вивчення проблеми підготовки молоді до свідомого батьківства та розробка відповідних розвивальних програм. 


\section{Література}

1. Біла I.М. Структурна модель розвитку здібностей в онтогенезі / Біла I.М. // Соціалізація і ресоціалізація особистості в умовах сучасного суспільства: Матеріали V Міжнародної науково-практичної конференції (11-12 листопада 2016 р., м. Київ) / за ред. О.І. Власової та ін. - К.: Вид-во «Віваріо», 2016. - С.168169.

2. Базові передумови появи та ресоціалізації дітей та молоді групи ризику / Т. В. Говорун // ScienceRise. - 2015. - № 8(1). - C. 8489. - Режим доступу: http://nbuv.gov.ua/UJRN/ texc_2015_8(1)15

3. Гиппенрейтер Ю.Б. Общаться с ребенком. Как? / Ю.Б.Гиппенрейтер, - М.: ЧеРо, 2001. 240 с.: ил.

4. Дружинин В.Н. Психология общих способностей / В.Н.Дружинин. - СПб.: Издательство “Питер”, 2000. - 368 с.: (Серия “Мастера психологии").

5. Дружинин В.Н. Психология семьи / В.Н.Дружинин. - М.: “КСП”, 1996. - 160с.

6. Лисина М.И. Проблеми онтогенеза общения / М.И.Лисина // Науч.-исслед. Ин-т общей и педагогической психологии Акад. пед. наук СССР. - М.: Педагогика, 1986. - 144 с.

7. Непомнящая Н.И. Становление личности ребенка 6-7 лет / Н.И.Непомнящая // Науч.-исслед. ин-т общей и педагогической психологии Акад. пед. наук СССР. - М.: Педагогика, 1992. - 180 с.

8. Рубинштейн С.Л. Способности // Психология индивидуальных различий / под ред. Ю.Б. Гиппенрейтер, В.Я.Романова. - 3-е изд., перераб.и доп. - М.: АСТ: Астрель, 2008. - С.3146.

9. Субботский Е.В. Ребенок открывает мир: Кн. для воспитателя дет. сада. / Е.В.Субботский. - М.: Просвещение. - 1991. - 207 с.

10. Шнейдер Л.Б. Семья: оглядываясь вперед / Л.Б.Шнейдер. - СПб.: Питер, 2013. - 368 с.: ил. - (Серия «Мастера психологии»).
УДК 159.9.01

\section{Bila I.M. \\ Doctor of Psychological Sciences, Professor \\ Genesis of personality in conditions of family interaction}

During our studies for the problem creating personality in the family environment, we proved that family interaction is done by creating personal targets that define the life trajectory, vector of ability, successful life strategy.

It was found that in the family, along with other emerging and communication skills, interaction, abilities, personal characteristics and ensure success in the implementation of various activities and as a result - successful adaptation. It was found connection between the living conditions and upbringing in the family and the type of child. According to the studies, the most common developmental sources. The most important way is the democratic style of family upbringing, characterized by a high degree of verbal communication between parents and children, inclusion of children in discussing family problems, willingness of the parents always come to the rescue, promotion of being active, curiosity, creativity, providing child leeway.

Family interaction that activates the cognitive, productive activities, maintains interest and motivation to its process, stimulates the development of personal-value, cognitive and creative areas and is an essential factor of formation and manifestation abilities of the child that can adapt to any, even the difficult living conditions.

Enhancing positive developmental interference in the family manifested in increasing the level of pedagogical knowledge of the parents, which affects the development, the child's behavior and contributes to the genesis of personality. 